\title{
Contemporary Practices of Musharakah in Financial Transactions
}

Takao Moriguchi, Mudeer Ahmed Khattak, Muhammad Farhan,Mohamad Firdaus, Asas Worasutr, Andi Lukman Hakim, Fikry Musthafa, Aishath Muneeza

International Centre for Education in Islamic Finance (INCEIF), The Global University of Islamic Finance, Malaysia

\begin{abstract}
Musharakah, which is translated as "joint venture or partnership" or "profit and loss sharing contract" is regarded as an ideal financing contract in Islamic finance. Musharakah has been applied to Islamic banking and Islamic capital market across the world and it is also proposed as one of alternative model in takaful business. Musharakah contract is also combined with other contracts and interesting products such as Musharakah Mutanaqisa has been developed. However, there are considerations concerning the principles of Shariah. This paper aims to discuss these matters and offer recommendations in order for Musharakah to be more widely accepted and adopted by the Muslim communities across the world. It is anticipated further research can be conducted to find out the implication of applying AAOIFI resolution on Musharakah or equity based products to find out the effect of it on different jurisdictions with different domestic laws and rules.
\end{abstract}

Paper Type: Viewpoint

Keywords: Islamic Finance, Musharakah, Shariah, Takaful, Equity Participation Contract, Profit and Loss sharing, Financing Contract, Sukuk 


\section{Introduction}

Musharakah literally means sharing or to share. Similar to a joint venture, Musharakah involves a partnership between two parties which conforms to the principles of profit and loss (Zaher and Kabir Hassan, 2001). Participatory finance through Musharakah has been widely used since ancient times (Zaher and Kabir Hassan, 2001), especially in Muslim world (Wilson, 1997). Typically, such financing arrangement is established by an Islamic financial institution (financier) and a client (or entrepreneur). There are certain Shariah conditions for Musharakah contract to be valid. Firstly, distribution of profit and loss must be agreed in advance, whereby profits are shared in pre-agreed ratio and losses should be borne in proportion to equity participation (Usmani, 1999; Zaher and Kabir Hassan, 2001). Secondly, all partners must contribute capital in cash or assets (Ahmed, 2008; Usmani, 1999). Lastly, each partner has a right but not obligation to involve in the management of the Musharakah's business (Usmani, 1999). This paper discusses various application of Musharakah concept in banks, capital markets, and takaful around the World.

\section{Musharakah in Banks}

Musharakah plays a significant role in financing business operations based on the principles Shariah (the Islamic Law), which prohibit interest from loans (Usmani, 1999). Musharakah allows the financier to receive a return according to a predetermined ratio; however, in the event of losses, the financer will also share with the entrepreneur in any losses. According to the Shariah principles, interest is "an unjust instrument of financing" (Usmani, 1999: 203) since it represents unfairness and injustice for both creditor and debtor: on one hand, it is unjust for the creditor on claiming a fixed rate of return in the case of high-yielding profits; on the other hand, it is unjust for the debtor to pay for the loan and interest in the event of losses (Usmani, 1999). If a financier aims to make profit through financing a business venture, the financier should also take the risk of making financial losses (Usmani, 1999). In a typical Musharakah contract, both bank and the client have their shares on the venture, and both parties have a right to its management (Usmani, 1999; Zaher and Kabir Hassan, 2001). Bank can also exercise the voting right which corresponds to their share of the firm and representative of bank can sit in the board room (Zaher and Kabir Hassan, 2001).

Apart from financing long-term investment projects, Musharakah is also commonly used for funding entrepreneurs the working capital to purchase raw materials or goods (Usmani, 1999) as well as transactional banking service in the form of Letter of Credit (L/C) (Ahmed, 2008; Usmani, 1999). Additionally, Musharakah can be used for financing imports and exports (Usmani, 1999). An exporter or importer can arrange for a single transaction on the basis of Musharakah and share the profit with the financier according to a pre-agreed ratio (Usmani, 1999).

International Journal of Management and Applied Research, 2016, Vol. 3, No. 2 
In international trade, the use of Islamic L/C is regulated by the Uniform Custom and Practice (UCP) 600 which was established by International Chamber of Commerce (Oseni, 2013). This can be an issue in terms of documentation due to the use of "interest" on the UCP regulation. The normal principle of Islamic law is that, riba (interest) is prohibited in the holy Quran (Usmani, 1999; Zaher and Kabir Hassan, 2001) and a bank is not allowed to collect a fee or commission (Oseni, 2013). The intention of establishing Islamic banking and finance was the desire of Muslims to conduct financial activities that comply with the principles of Shariah (Islamic law). Therefore, as highlighted by Oseni (2013), there are certain inconsistencies that need to be resolved in order to ensure a viable framework in international trade.

Musharakah Mutanaqisa (Diminishing Musharakah) is one of Musharakah's forms that is commonly used in home financing. In reference to the Shariah Standards published by the Accounting and Auditing Organization for Islamic Financial Institutions (AAOIFI), diminishing musharakah is "a form of partnership in which one of the partners promises to buy the equity share of the other partner gradually until the title to the equity is completely transferred to him" (AAOIFI, 2008: 217). In home financing, the bank and the customer jointly acquire a property, the bank then leases its share to the customer and gradually, the customer buys bank's share in the property. Thus this product consists of three contracts: partnership, leasing, and sale.

According to the Asian Institute of Finance (2013), since more than one contract are involved in concluding Musharakah Mutanaqisa, it may raise a Shariah issue in practice. Shariah prohibits the use of multiple contracts in the same agreement. In addition, the binding promise (wa'd) which force the customer to take over the remaining equity shares owned by the bank may cause this contract to be Shariah noncompliant as Islam is against coercion. Furthermore, customer's gradual purchase of equity on the basis of values given in the initial contact can cause Shariah compliant issue. Due to these issues, Musharakah Mutanaqisa is not so prevailing in Gulf Cooperation Council (GCC) countries such as Saudi Arabia, Kuwait, the United Arab Emirates, Qatar, Bahrain, and Oman in comparison with Malaysia.

\section{Musharakah in Capital Markets}

Musharakah plays an influential role in Islamic Capital Market. In most countries, the Islamic capital market has two legs, the equity or stock market and the bond (sukuk) market. Musharakah has been frequently used in both markets.

For equity market, in the first place, stocks are based on Musharakah concept. However, in order to be in Shariah compliance, stock-screening process needs to be applied, such as the one proposed by Shariah Advisory Council of Securities Commission, Malaysia (SAC's Screening), the one proposed by Dow Jones (DJ's Screening) and the one proposed by FTSE Group (FTSE's screening). Despite the variations in approaches adopted by different jurisdictions, the process of Shariah

International Journal of Management and Applied Research, 2016, Vol. 3, No. 2 
stock screening can be generally divided into three: sector screening, financial screening, and dividend purification (Kureshi and Hayat, 2014).

The Shariah Advisory Council (SAC) of the Securities Commission (SC) Malaysia adopts a two-tier quantitative approach which applies the business activity benchmarks and the financial ratio benchmarks; and if those thresholds are satisfied, the listed securities will be assessed using qualitative elements such as public perception (Bank Negara Malaysia, 2013) and the core activities of the company are considered as maslahah (benefit in general) and important (Kureshi and Hayat, 2014). Through the SAC's screening, any dividend purification standard has not been adopted.

On the other hand, the Dow Jones's screening process consists of two stages: industry screen and financial ratio screen (S\&P Dow Jones Indices, 2016). Initially, stocks are screened to ensure that each involved in Shariah compliant activities. Companies that engage in non-Shariah compliant activities, such as producing or selling tobacco, will be filtered out. The remaining companies are then further screened on a financial basis. The threshold used in financial screening is more volatile measures compared to those used under SAC's Screening: it uses 24 month trailing market capitalisation (S\&P Dow Jones Indices, 2016).

The FTSE's screening is adopting the same basic methodology as the Dow Jone's screening and applies business activity screening as their first assessment, followed by financial ratio screening (FTSE, 2016). A key difference from Dow Jone's screening is that the FTSE's screening uses book value of total assets (rather than market capitalisation value) and it adopts an additional threshold: ratio of total interest and non-compliant activities income (FTSE, 2016). Moreover, an independent screening is undertaken by an organisation that has global network of Shariah scholars -- Yasaar Limited (FTSE, 2016).

There are a number of Shariah issues regarding the screening process, namely, the $5 \%$ and $20 \%$ of business activity benchmark used by SAC's when completing quantitative assessment (Kureshi and Hayat, 2014), use of market capitalisation as a denominator for the calculation of financial ratios under DJ's screening, and usage of a third party for Shariah screening under FTSE's screening. Comparison table of Shariah screening process is presented in Table 1.

Table 1: Comparison of Shariah Screening Process

\begin{tabular}{llll}
\hline & SAC's Screening & Dow Jones' Screening & FTSE's Screening \\
\hline $\begin{array}{l}\text { Scope } \\
\text { Screener }\end{array}$ & Malaysian stocks & Global stocks & Global stocks \\
Focus & $\begin{array}{l}\text { Regulator } \\
\text { Activity-based }\end{array}$ & Index provider & Index provider \\
& Benchmarks & Industry screening & Industry screening \\
Denominator & Total asset & Market capitalisation & Total asset \\
Screening & Sector/ financial & $\begin{array}{l}\text { Sector/ financial/ dividend } \\
\text { purification }\end{array}$ & $\begin{array}{l}\text { Sector/ financial/ dividend } \\
\text { purification }\end{array}$
\end{tabular}

International Journal of Management and Applied Research, 2016, Vol. 3, No. 2 


$\begin{array}{llll}\begin{array}{l}\text { Applied } \\ \text { financial } \\ \text { ratio }\end{array} & \text { Total debt/ total assets } & \text { Total debt/ market cap } & \text { Total debt/ total assets } \\ & \text { Cash/ total assets } & \begin{array}{l}\text { (Cash }+ \text { interest bearing } \\ \text { securities) / market cap }\end{array} & \begin{array}{l}\text { (Cash }+ \text { interest bearing } \\ \text { securities) / total assets }\end{array} \\ & \text { Receivables / market cap } & \text { Receivables / total assets } \\ & & \begin{array}{l}\text { (Interest + non-compliant } \\ \text { activities income)/ total } \\ \text { revenue }\end{array}\end{array}$

Source: Bank Negara Malaysia, 2013: 4; FTSE, 2016

Based on those Shariah compliant stocks, Shariah-compliant funds -- such as Islamic mutual funds, Islamic ETFs (Exchange Trade Funds), Islamic REITs (Real Estate Investment Trusts), Islamic Private Equity Funds -- have been developed; and Musharakah (or in some cases is Musharakah Mutanaqisah) is frequently used as a key contract. According to the Securities Commission (2013), a third party or one of the partners (or issuers) may be appointed as the manager to manage the Musharakah venture.

In sukuk market (i.e. bond market), Musharakah (together with Musharakah Mutanaqisah) is of the commonly used financing contracts. According to the Rating Agency Malaysia (RAM), 41\% of corporate sukuk are based on Musharakah (RAM Rating Services Berhad, 2012). Sukuk Musharakah is issued for the purpose of using the funds to create a new project and to develop a financing system for transactionbased business partnership. Sukuk holders who are involved in this partnership will be sharing profits based on an agreement with an agreed ratio while losses will be sharing based on sukuk's holding (Bi, 2008).

In 2007, Sheikh Muhammad Taqi Usmani, the president of the AAOIFI Shariah board, published a paper titled "Sukuk and their Contemporary Applications" in which he commented that majority of the Sukuk in the market (especially those using a Musharakah structure) are not in line with the principles of Shariah. Usmani's opinions can be summarised into three elements: firstly, the payment of any surplus as an incentive fee to the originating party in the transaction, does not adhere to the Islamic finance concept as it will limit the profit and loss sharing between them. Secondly, the interest-free loan arranged to investors in the event of cash shortfall is not allowed. It is basically a form of fixing the periodic returns to the investors, and thus they are not taking the risk that entitles them to a reward. Thirdly, purchase undertaking at face value is not permissible. This implies that the originating party in fact guarantees principal amount of the investors, which is not in line with the concept of profit and loss sharing (Usmani, 2007).

His paper has been widely circulated since 2007 (Bi, 2008), and the global sukuk market shrunk from US\$50bn in 2007 to approximately \$14.9bn in 2008 (Richter, 2009). Although it is not clear whether such decline was caused by his criticisms or global financial crisis, considering the gradual decline of Musharakah share under sukuk market, it is assumed here that Shariah issues have some effects on

International Journal of Management and Applied Research, 2016, Vol. 3, No. 2 
Musharakah's applicability in the sukuk market. Following to the controversy caused by the statement made by Muhammad Taqi Usmani, the AAOIFI Shariah board issued a "Resolution on Sukuk" in 2008 which aims to provide some guidance in relation to Sukuk structures (Bi, 2008; Salah, 2010).

The Shariah issues concerning sukuk can be discussed under four headings, which are: ownership, liquidity facility, purchaser undertaking, and underlying asset. The first issue revolves around the ownership of sukuk holders and the right to transfer assets. Sukuk are Shariah-compliant financial instruments and thus the transfer of ownership should be in accordance with the Shariah principles. However, the enforcement of the Shariah law in different countries and legal systems may pose certain challenges to sukuk holders (Tan, 2009). In Malaysia, for instance, sukuk holders are allowed to transfer beneficial ownership (Ellias et al., 2013) and yet there is no concept of beneficiary ownership in Indonesia (Tan, 2009). Such discrepancies illustrate that the different views regarding ownership status of sukuk holders from the Shariah perspective (Ellias et al., 2013); and this poses a problem for sukuk holders and certain investors due to the transfer of risk and control (Tan, 2009).

A second consideration of sukuk is liquidly facility. The AAOIFI Shariah Board disapproves the practice of giving loan by the manager to Sukukholders in the event of short fall (Ellias et al., 2013; Tan, 2009). For AAOIFI, such practice is a departure from the Shariah principles which is based on profit-loss sharing. The Shariah Advisory Council (SAC), on the other hand, is of the view that the issuer is allowed to make advanced payment facility (Securities Commission Malaysia, 2013).

Another issue to be discussed is underlying asset. Shariah scholars and practitioners have different views regarding the tradability of sukuk at the secondary market. According to AAOIFI, sukuk must not include receivables or debts (Ellias et al., 2013; Tan, 2009). However, the SAC accepts the principle of Bay' al dayn (debt trading) as one of the Islamic capital market instruments (Ellias et al., 2013).

And last but not least is the issue of purchaser undertaking. The practice of issuer granting purchase undertaking has been heavily debated by Shariah scholars and practitioners. On one hand, AAOIFI disapprove the practice of buying the assets of the partnership at face value (AAOIFI, 2010). On the other hand, the SAC accepts "the purchase undertaking at a price representing the face value of the Sukuk at maturity or following an event of default" (Ellias et al., 2013: 9).

Table 2 summarises the views of AAIOFI and Shariah Advisory Council (SAC) regarding Sukuk in terms of ownership, underlying asset, liquidity facility, and purchaser undertaking by the originator. In short, the interpretation of AAOIFI on sukuk is primarily based on Taqi Usmani's opinions on equity-based sukuk (Musharakah sukuk), in which interest-free loans to the sukukholders in case of shortfalls is not allowed, purchase undertaking at nominal value is not permissible, debt trading is not prohibited.

International Journal of Management and Applied Research, 2016, Vol. 3, No. 2 
Table 2: Difference Views in Sukuk

\begin{tabular}{|c|c|c|}
\hline Issues & SAC's view & AAIOFI's view \\
\hline Ownership & $\begin{array}{l}\text { Transfer of beneficial ownership is } \\
\text { allowed; true sale is not always required }\end{array}$ & $\begin{array}{l}\text { Real transfer of ownership (i.e. true } \\
\text { sale) is required }\end{array}$ \\
\hline $\begin{array}{l}\text { Underlying } \\
\text { asset }\end{array}$ & $\begin{array}{l}\text { Receivables of debts can be included. } \\
\text { Bay' al dayn is allowed }\end{array}$ & $\begin{array}{l}\text { Receivables or debts cannot be } \\
\text { included. Bay' al dayn is not allowed }\end{array}$ \\
\hline $\begin{array}{l}\text { Liquidity } \\
\text { facility }\end{array}$ & Advance payment facility is allowed & $\begin{array}{l}\text { Establishment of reserve account is } \\
\text { allowed, but interest free loan facility is } \\
\text { not allowed }\end{array}$ \\
\hline $\begin{array}{l}\text { Purchaser } \\
\text { undertaking } \\
\text { by the } \\
\text { originator }\end{array}$ & $\begin{array}{l}\text { Undertaking to purchase assets from the } \\
\text { sukuk holders for its nominal value as } \\
\text { one option }\end{array}$ & $\begin{array}{l}\text { Purchase undertaking at nominal value } \\
\text { is not allowed; however, purchase } \\
\text { undertaking at market value or at a } \\
\text { price to be agreed on at the sales timing } \\
\text { is allowed }\end{array}$ \\
\hline
\end{tabular}

Sources: AAIOFI, 2008; Ellias et al., 2013 ; Securities Commission Malaysia, 2014; Tan, 2009

The above issues pose challenges to the sukuk holders and operators. It is quite difficult to design and implement a one-size-fits-all approach in addressing these challenges because there are many different types of jurisdictions, with different national cultures and priorities.

\section{Takaful}

Takaful is an alternative to conventional insurance contract, whereby the bank acts a managing trustee and the participants pay instalments into an Islamic mutual insurance type of fund (Nahar, 2015; Kwon, 2007; Zaher and Kabir Hassan, 2001). According to Nahar (2015) and Ahmad (2014), the Takaful insurance is primarily based on the Islamic principles of ta'awun (mutual cooperation) and tabarru'at (unilateral gratuitous contribution). However, some Shariah scholars and practitioners questioned the contractual arrangements of the Takaful are in accordance to Shariah requirement (Ahmad, 2014). Furthermore, there is no regulation in place to ensure that Islamic insurances are truly Shariah compliant (Masud, 2011).

In 2010, the International Islamic Fiqh Academy (IIFA) - a subsidiary organ of the Organization of Islamic Cooperation (OIC) - call for a re-examination of all juristic characterisations applied in Takaful practices in a conference "Cooperative Insurance: Dimensions, Perspectives, and the Position of the Islamic Shariah" (Ahmad, 2014). Ahmad (2014) proposed the concept of cooperative partnership (Musharakah Ta'awuniyyah) takaful model, which he claims that it is more fundamentally supported by evidence from the Shariah sources. The proposed Musharakah Ta'awuniyyah Takaful model is intended to provide mutual benefits to the participants of Takaful model without engaging them into a commutative contract that is more akin to commercial partnership (Ahmad, 2014). On one hand, the ta'awun concept allows participants to make donations with the intention to help each other within the Takaful group. On the other hand, the Musharakah concept allows surplus or deficit of the funds to be shared in accordance with the principles of Musharakah.

International Journal of Management and Applied Research, 2016, Vol. 3, No. 2 
Therefore, Musharakah Ta'awuniyyah can be defined as a mutual and bilateral contract made by a group of people based on the agreement and consent to combine the two elements of safeguarding property and mutual cooperation among themselves (Ahmad, 2014). However, this model has not yet been practiced in any jurisdiction as it is still in the experimental stage.

\section{Conclusion and Recommendation}

As at today, Musharakah is one of widely used Islamic financing contracts across the world. Musharakah based products are mainly developed in banks and capital markets. In banks, Musharakah is mostly used in the form of partnership while in capital markets, Musharakah used in both equity and debt markets. However, some issues such as the involvement of the bank in managing the business, the use of interest word in Musharakah-based L/C, the use of multiple contracts in the same agreement and the binding promise (wa'd) in Musharakah Mutanaqisa were noticed in the application of Musharakah.

Usmani (1999: 204) acknowledged that: "Undoubtedly, musharakah embodies a number of practical problems in its full implementation as a universal method of financing". Nonetheless, Usmani also highlighted that one of the "real and ideal instruments of financing in Shariah" is Musharakah (Usmani, 2002: xv). He further adds that: "Islamic philosophy cannot be translated into reality unless the use of musharakah is expanded by Islamic banks" (Usmani, 2002: 313). Based on his comments and views of other scholars, we recommend that Musharakah should be further promoted globally, hence Islamic finance expands more towards equity based products that shares profits and risks among relevant parties, and further exploration of potential needs, shifting from debt-based financing (such as Murabahah or Ijarah) to equity-based financing in Islamic banks should be encouraged.

Furthermore, in order to achieve these, we recommend that relevant Shariah rules should be standardised globally. Table 3 summarises the Musharakah practices across the world. As the Islamic finance industry continues to grow at global scale, there is a need for a robust governance system and internationally recognised standards. Given the diverse jurisdictions, it is important for the Muslim economists and Shariah practitioners to come out with standards which are more widely acceptable at global level (Tan, 2009). Shariah boards and relevant professional bodies should have a clear mandate to provide effective Shariah governance. In this way, it will be able to minimise different interpretation of Shariah rules among regions that may prevent growth of Islamic finance globally. For the purpose of standardisation of Shariah rules, we further suggest that basic concept of Musharakah (i.e. profit and risk sharing among parties) should be more diligently observed and in case of equity-based sukuk, the AAOIFI resolution should be implemented. Further research on the implication of applying AAOIFI resolution on this matter needs to be conducted to find out the effect of it on different jurisdictions with different domestic laws and rules.

International Journal of Management and Applied Research, 2016, Vol. 3, No. 2 
Table 3: Musharakah Practices across the World

\begin{tabular}{|c|c|c|}
\hline Country & Practices & Bank Name \\
\hline Ireland & $\begin{array}{l}\text { Diminishing Musharakah/Hire } \\
\text { Purchase } \\
\text { Musharakah Deposit }\end{array}$ & Regulation only \\
\hline Luxembourg & $\begin{array}{l}\text { Sukuk al-Musharakah } \\
\text { Undertakings for Collective } \\
\text { Investments in Transferable Securities } \\
\text { (UCITS) } \\
\text { Specialised Investment Funds (SIF) }\end{array}$ & $\begin{array}{l}\text { KBL European Private Bankers (KBL } \\
\text { epb)/Islamic Liquidity Management } \\
\text { Blackrock } \\
\text { Alliance for Luxembourg Islamic Finance } \\
\text { (ALIF) } \\
\text { Sedco Capital }\end{array}$ \\
\hline Turkey & Sukuk al-Musharakah & Regulation only \\
\hline $\begin{array}{l}\text { United } \\
\text { Kingdom }\end{array}$ & $\begin{array}{l}\text { Sukuk al-Musharakah } \\
\text { Diminishing Musharakah }\end{array}$ & $\begin{array}{l}\text { Sanctuary Building/ Lloyds TSB } \\
\text { Al Rayan Bank }\end{array}$ \\
\hline USA & $\begin{array}{l}\text { Sukuk al-Musharakah } \\
\text { Diminishing Musharakah }\end{array}$ & $\begin{array}{l}\text { East Cameron Gas } \\
\text { Devon Bank } \\
\text { Zayan Finance } \\
\text { Guidance Residential } \\
\text { Lariba - American Finance House/Bank of } \\
\text { Whittier }\end{array}$ \\
\hline Saudi Arabia & $\begin{array}{l}\text { Equity Financing } \\
\text { Musharakah Letter of Credit (L/C) } \\
\text { Musharakah for Corporate Finance }\end{array}$ & $\begin{array}{l}\text { Islamic Development Bank (IDB) } \\
\text { Al-Rajhi Bank }\end{array}$ \\
\hline Oman & $\begin{array}{l}\text { Musharakah in Agricultural Sector } \\
\text { Diminishing Musharakah: Business } \\
\text { Diminishing Musharakah: Property } \\
\text { Diminishing Musharakah : Home } \\
\text { Financing }\end{array}$ & $\begin{array}{l}\text { Government Policy } \\
\text { MUZN Islamic Banking } \\
\text { MEETHAQ Islamic Banking }\end{array}$ \\
\hline Kuwait & $\begin{array}{l}\text { Diminishing Musharakah: Home } \\
\text { Financing }\end{array}$ & Kuwait Finance House \\
\hline Bahrain & Musharakah Financing & Islamic Bank of Bahrain \\
\hline UAE & $\begin{array}{l}\text { Musharakah Financing } \\
\text { Cooperate sukuk: Al Musharakah }\end{array}$ & $\begin{array}{l}\text { Abu Dhabi National Bank } \\
\text { Dubai Islamic Bank } \\
\text { Emirates Islamic Bank }\end{array}$ \\
\hline Egypt & $\begin{array}{l}\text { Musharakah Business Financing } \\
\text { (Agriculture, Industry) }\end{array}$ & $\begin{array}{l}\text { Al Baraka Bank Egypt } \\
\text { AT. Asset Management } \\
\text { A.T Brokerage } \\
\text { Faisal Islamic Bank } \\
\text { Ridge Islamic Capital }\end{array}$ \\
\hline South Africa & $\begin{array}{l}\text { Musharakah Business Property } \\
\text { Financing }\end{array}$ & $\begin{array}{l}\text { Absa Islamic Banking (Islamic window) } \\
\text { Al-Baraka Bank }\end{array}$ \\
\hline Morocco & $\begin{array}{l}\text { Diminishing Musharakah } \\
\text { Musharakah Business Financing }\end{array}$ & $\begin{array}{l}\text { Attijari Wafa Bank } \\
\text { Banque Populaire } \\
\text { BMCE } \\
\text { BMCI }\end{array}$ \\
\hline Sudan & $\begin{array}{l}\text { Musharakah Business Financing } \\
\text { (Agriculture, Industry, Trading) } \\
\text { Sukuk Al Musharakah }\end{array}$ & $\begin{array}{l}\text { African Bank for Trade and Development } \\
\text { Agricultural Bank } \\
\text { Animal Resources' Bank }\end{array}$ \\
\hline Malaysia & $\begin{array}{l}\text { Sukuk Musharakah } \\
\text { Diminishing Musharakah } \\
\text { Outward Letter of Credit-i }\end{array}$ & $\begin{array}{l}\text { Bank Islam Malaysia Berhad } \\
\text { Maybank Islamic } \\
\text { Affin Islamic Bank } \\
\text { AmIslamic Bank } \\
\text { CIMB Islamic Bank }\end{array}$ \\
\hline
\end{tabular}

International Journal of Management and Applied Research, 2016, Vol. 3, No. 2 
$\begin{array}{ll}\text { Indonesia } & \text { Diminishing Musharakah } \\ & \text { Sukuk Diminishing Musharakah }\end{array}$

Singapore

Brunei

Diminishing Musharakah (Home financing)

Musharakah Corporate Financing BIBD Musharakah Musahamah

Al-Bai Tradable Musharakah Certificate
Public Islamic Bank

RHB Islamic Bank

Bank Muamalat Malaysia

PT Bank Muamalat Indonesia

PT Bank syariah mandiri

PT Mega Bank Syariah

PT Bank syariah BRI

PT Bank Syariah Bukopin

PT panin bank syariah

PT bank victoria syariah

PT BCA syariah

PT Bank Jabar dan Banten

PT Bank syariah BNI

PT Maybank Indonesia syariah

PT Bank Tabungan Pensiunan Nasional Syariah UOB

Majlis Ugama Islam Singapura (MUIS)

Monetary Authority of Singapore (MAS)

(Diminishing Musharakah -only regulation in place)

Bank Islam Brunei Darussalam (BIDB)

\section{References}

1. Ahmad, A. U. F. (2014), Exploring the model of Musharakah Ta 'a wuniyyah in Takaful. International Shariah Research Academy for Islamic Finance.

2. Ahmed, G. F. (2008), “The implication of using profit and loss sharing modes of finance in the banking system, with a particular reference to equity participation (partnership) method in Sudan", Humanomics, Vol. 24, No. 3, pp.182 - 206. http://dx.doi.org.liverpool.idm.oclc.org/10.1108/08288660810899359

3. Accounting and Auditing Organization for Islamic Financial Institutions (AAOIFI) (2008), Shariah Standard, No.12, 5/1.

4. Accounting and Auditing Organization for Islamic Financial Institutions (AAOIFI) (2010), Shariah Standard, No. 12, item 3/1/6/2.

5. Asian Institute of Finance (2013), Musharakah Mutanaqisah Home Financing. [Online] Available from: http://www.aif.org.my/clients/aif_d01/assets/multimediaMS/publication/CaseStud y_Musharakah.pdf [Accessed on 1 May 2016].

6. Bank Negara Malaysia (2013), Shariah Screening Methodology: Adopting a Twotier Quantitative Approach, [Online] Available from:

http://www.mifc.com/?ch=28\&pg=72\&ac $=54 \& b b=$ uploadpdf [Accessed on 28 April 2016].

International Journal of Management and Applied Research, 2016, Vol. 3, No. 2 
7. Bi, F. (2008), “AAOIFI Statement on Sukuk and its implications”, Norton Rose Fulbright [Online] Available from:

http://www.nortonrosefulbright.com/knowledge/publications/16852/aaoifistatement-on-sukuk-and-its-implications [Accessed on 28 April 2016].

8. Ellias, M. R. F.; Muhamad Nasir Haron, M. N. and Mohammed, M. F. (2013), "Shariah issues in Sukuk", presented at the Shariah Forum, KLIFF, 23 September 2013, Istana Hotel, Kuala Lumpur, [Online] Available from:

http://www.maybank2u.com.my/iwov-resources/islamicmy/document/my/en/islamic/scoe/knowledge-centre/researchpaper/Shariah_\%20Issues_in_Sukuk.pdf [Accessed on 29 April 2016].

9. FTSE (2016), FTSE SET Shariah Index [Online] Available from: http://www.ftse.com/Analytics/FactSheets/Home/DownloadSingleIssue?issueNam e=FSTSH [Accessed on 29 April 2016].

10. Kureshi, H. and Hayat, M.(2014), Contracts and Deals in Islamic Finance: A User?s Guide to Cash Flows, Balance Sheets, and Capital Structures, Singapore: John Wiley and Sons.

11. Kwon, W. J. (2007), "Islamic Principle and Takaful Insurance: Re-evaluation", Journal Of Insurance Regulation, Vol. 26, No. 1, pp. 53-81.

12. Masud, H. (2011), “Takaful: An Innovative Approach to Insurance and Islamic Finance", University of Pennsylvania Journal of International Law, Vol. 32, No. 4, pp. 1133-1164.

13. Nahar, H. S. (2015), “Insurance vs Takaful: identical sides of a coin?”, Journal of Financial Reporting and Accounting, Vol. 13, No. 2, pp. 247 - 266. https://doi.org/10.1108/JFRA-02-2015-0029

14. Richter, F. (2009), “Gulf sukuk market revival seen unlikely in 2009”, Reuters. [Online] Available from: http://www.reuters.com/article/sukuk-outlookidUSLS10157820090128 [Accessed on 28 April 2016].

15. Oseni, U. (2013), "Towards restructuring the legal framework for payment system in international Islamic trade finance", Journal Of International Trade Law \& Policy, Vol. 12, No. 2, pp. 108-129. https://doi.org/10.1108/JITLP-10-2012-0016

16. RAM Rating Services Berhad (2012), Riding the Momentum, [Online] Available from: http://www.mifc.com/?ch=28\&pg=72\&ac=40\&bb=uploadpdf [Accessed on 28 April 2016].

17. S\&P Dow Jones Indices (2016), Screens for Shari'ah compliance [Online] Available from: https://www.djindexes.com/islamicmarket/?go=shariahcompliance [Accessed on 28 April 2016].

18. Salah, O. (2010), "Islamic Finance: The Impact of the AAOIFI Resolution on Equity-Based Sukuk Structures", Law And Financial Markets Review, Vol. 4, No. 5, pp. 507-517.

19. Securities Commission Malaysia (2014), Guidelines on Sukuk, [Online] Available from: http://www.sc.com.my/wp-

International Journal of Management and Applied Research, 2016, Vol. 3, No. 2 
content/uploads/eng/html/resources/guidelines/bondmkt/sukukGuidelines_080120 14.pdf. [Accessed on 28 April 2016].

20. Tan, W. Y. (2009), "Sukuk: Issues and the Way Forward”, International Legal News, Vol. 6, No. 2, [Online] Available from:

http://www.iln.com/articles/pub_1674.pdf [Accessed on 29 April 2016].

21. Wilson, R. (1997), "Islamic finance and ethical investment", International Journal of Social Economics, Vol. 24, No. 11, pp.1325 - 1342. https://doi.org/10.1108/03068299710193624

22. Usmani, M. T. (1999), "The Concept of Musharakah and its Application as an Islamic Method of Financing”, Arab Law Quarterly, Vol. 14, No. 3, pp. 203-220. https://doi.org/10.1163/026805599125826435

23. Usmani, M. T. (2002), An Introduction to Islamic Finance, The Hague: Kluwer Law International.

24. Usmani, M. (2007), Sukuk and their Contemporary Applications. Bahrain: AAOIFI Shariah Council.

25. Zaher, T. S. and Kabir Hassan, M. (2001), "A Comparative Literature Survey of Islamic Finance and Banking”, Financial Markets, Institutions \& Instruments, Vol. 10, No. 4, pp. 155-199. https://doi.org/10.1111/1468-0416.00044

International Journal of Management and Applied Research, 2016, Vol. 3, No. 2 